\title{
Mindfulness-Meditation-Based Pain Relief Is Not Mediated by Endogenous Opioids
}

\author{
Fadel Zeidan, ${ }^{1}$ Adrienne L. Adler-Neal, ${ }^{1}$ Rebecca E. Wells, ${ }^{2}$ Emily Stagnaro, ${ }^{4}{ }^{\circ}$ Lisa M. May, ${ }^{5}$ James C. Eisenach, ${ }^{3}$ \\ John G. McHaffie, ${ }^{1}$ and Robert C. Coghill ${ }^{6}$ \\ ${ }^{1}$ Department of Neurobiology and Anatomy, ${ }^{2}$ Department of Neurology, and ${ }^{3}$ Department of Anesthesiology, Wake Forest School of Medicine, Winston- \\ Salem, North Carolina 27157, ${ }^{4}$ Department of Psychology, Wake Forest University, Winston-Salem, North Carolina 27109, ${ }^{5}$ Department of Biology, \\ University of Oregon, Eugene, Oregon 97403, and ' ${ }^{D}$ epartment of Anesthesiology, Cincinnati Children’s Hospital Medical Center, Cincinnati, Ohio 45229
}

\begin{abstract}
Mindfulness meditation, a cognitive practice premised on sustaining nonjudgmental awareness of arising sensory events, reliably attenuates pain. Mindfulness meditation activates multiple brain regions that contain a high expression of opioid receptors. However, it is unknown whether mindfulness-meditation-based analgesia is mediated by endogenous opioids. The present double-blind, randomized study examined behavioral pain responses in healthy human volunteers during mindfulness meditation and a nonmanipulation control condition in response to noxious heat and intravenous administration of the opioid antagonist naloxone $(0.15 \mathrm{mg} / \mathrm{kg} \mathrm{bolus}+0.1 \mathrm{mg} / \mathrm{kg} / \mathrm{h}$ infusion) or saline placebo. Meditation during saline infusion significantly reduced pain intensity and unpleasantness ratings when compared to the control + saline group. However, naloxone infusion failed to reverse meditation-induced analgesia. There were no significant differences in pain intensity or pain unpleasantness reductions between the meditation + naloxone and the meditation + saline groups. Furthermore, mindfulness meditation during naloxone produced significantly greater reductions in pain intensity and unpleasantness than the control groups. These findings demonstrate that mindfulness meditation does not rely on endogenous opioidergic mechanisms to reduce pain.
\end{abstract}

Key words: cognitive; mindfulness meditation; naloxone; opioid; pain

\section{Significance Statement}

Endogenous opioids have been repeatedly shown to be involved in the cognitive inhibition of pain. Mindfulness meditation, a practice premised on directing nonjudgmental attention to arising sensory events, reduces pain by engaging mechanisms supporting the cognitive control of pain. However, it remains unknown if mindfulness-meditation-based analgesia is mediated by opioids, an important consideration for using meditation to treat chronic pain. To address this question, the present study examined pain reports during meditation in response to noxious heat and administration of the opioid antagonist naloxone and placebo saline. The results demonstrate that meditation-based pain relief does not require endogenous opioids. Therefore, the treatment of chronic pain may be more effective with meditation due to a lack of cross-tolerance with opiate-based medications.

\section{Introduction}

Opioidergic mechanisms have been repeatedly demonstrated to be involved in cognitive inhibition of pain (Bandura et al., 1987;

Received Dec. 2, 2015; revised Feb. 1, 2016; accepted Feb. 4, 2016

Author contributions:F.Z., R.E.W., L.M.M., J.C.E., J.G.M., and R.C.C. designed research; F.Z., A.L.A.-N., R.E.W., E.S., and J.C.E. performed research; F.Z., A.L.A.-N., E.S., and R.C.C. analyzed data; F.Z., A.L.A.-N., R.E.W., L.M.M., J.C.E., J.G.M., and R.C.C. wrote the paper.

This work was supported by the National Center for Complementary and Integrative Health (Grant K99AT008238), the Mind and Life Institute, and the Wake Forest Translational Science Institute.

The authors declare no competing financial interests.

Correspondence should be addressed to Fadel Zeidan, PhD, Department of Neurobiology and Anatomy, Wake Forest School of Medicine, 1 Medical Center Boulevard, Winston-Salem, NC 27157. E-mail: fzeidan@wakehealth.edu.

DOI:10.1523/JNEUROSCI.4328-15.2016

Copyright $\odot 2016$ the authors $\quad 0270-6474 / 16 / 363391-07 \$ 15.00 / 0$
Tracey et al., 2002; Wager et al., 2007). Pain relief produced by placebo (Levine et al., 1978; Grevert et al., 1983; Amanzio and Benedetti, 1999; Zubieta et al., 2005; Eippert et al., 2009), conditioned pain modulation (King et al., 2013), and attentional control (Sprenger et al., 2012) is reversed by administration of the opioid antagonist naloxone. Furthermore, brain regions associated with facilitating the cognitive modulation of pain, including the anterior cingulate cortex (ACC), orbitofrontal cortex (OFC), and insula, contain high concentrations of opioid receptors (Jones et al., 1991; Adler et al., 1997; Willoch et al., 1999; Casey et al., 2000; Willoch et al., 2004; Wager et al., 2007) and activation of these opioidergic systems (Petrovic et al., 2002; Zubieta et al., 2005; Bingel et al., 2006; Wager et al., 2007; Eippert et al., 2009; Sprenger et al., 2012) produces analgesia (Tracey et al., 2002; 
Bingel et al., 2006). Several of these brain regions, such as the ACC and prefrontal cortex (PFC), project to the periaqueductal gray (PAG) (Floyd et al., 2000), a structure that can also be directly activated by opioids. The PAG projects to the rostral ventral medulla (Beitz, 1982; Mantyh, 1983a, 1983b) and in turn projects to the spinal dorsal horn and can inhibit nociceptive processing via multiple neurotransmitter systems (Liebeskind et al., 1973).

Mindfulness meditation is another cognitive technique that can attenuate the subjective experience of pain. As implemented in our laboratory, this technique combines focused attention on the breath with objective appraisal of arising thoughts and sensations. Brain imaging has shown that mindfulnessmeditation-related pain reductions are associated with activation of the perigenual ACC, OFC, and anterior insula (Zeidan et al., 2011; Zeidan et al., 2015). Although activation of these regions could be suggestive of opioidergic mechanisms, given their high concentrations of opioid receptors, other patterns of brain activity raise the possibility of alternative mechanisms supporting mindfulness-meditation-induced pain relief. Specifically, mindfulness meditation significantly deactivates the thalamus (Zeidan et al., 2011; Zeidan et al., 2015), potentially reflecting cognitive gating of the transmission of sensory information to the cortex (Zeidan et al., 2011; Zeidan et al., 2012). Moreover, mindfulness meditation deactivates the PAG (Zeidan et al., 2015), a finding inconsistent with activation of this structure by opioiddependent cognitive pain-modulatory manipulations (Watkins and Mayer, 1982; Basbaum and Fields, 1984). To test the hypothesis of an opioid mechanism, the present double-blind, randomized psychophysical study examined subjective pain reports during mindfulness meditation in response to noxious heat stimulation during naloxone or saline administration.

\section{Materials and Methods Participants}

Ninety-five healthy, pain-free, and meditation-naive human volunteers recruited from the local community provided informed consent for the present study. Wake Forest School of Medicine's Institutional Review Board approved all study procedures. All subjects provided written, informed consent recognizing the following: (1) that they would experience painful, heat stimuli; (2) that all methods were clearly explained; and (3) that they were free to withdraw from the study without prejudice. Subjects were informed that the study was focused on assessing "if meditation is associated with the release of naturally occurring opiates" and that they "may receive intravenous administration of saline or naloxone, a relatively safe drug that blocks the transmission of opioid activity."

Seventy-eight participants ( 75 right-handed; mean age $=27 \pm 7$ years; 39 males; 39 females) successfully completed all study procedures (57 were white, 8 were Asian, 7 were black, 4 were Hispanic, 1 was Native American, and 1 self-identified as "mixed").

Seventeen recruited participants were excluded from the final analysis for a variety of reasons including age $(n=1)$, IV administration trouble $(n=2)$, equipment malfunction $(n=1)$, scheduling conflicts $(n=2)$, chronic pain $(n=1)$, sleeping through the meditation training $(n=2)$, pain insensitivity $(n=1)$, and procedural errors $(n=3)$. Importantly, 4 subjects experienced several adverse effects, including dizziness $(n=3)$ and syncope $(n=1)$, during the administration of the naloxone bolus. All of these subjects were white females with weights $<70 \mathrm{~kg}$. All four participants recovered rapidly after termination of the naloxone infusion.

\section{Sample size determination}

Based on our previous studies (Zeidan et al., 2010a; Zeidan et al., 2011; Zeidan et al., 2015) and sample size determination software $\left(\mathrm{G}^{*}\right.$ power, $3.1), 16$ subjects per group were considered sufficient to detect a signifi- cant difference (large effect size $=\eta_{\mathrm{p}}^{2}=.14$ ) between groups on a twosided, 0.05 test of proportions [repeated-measures (RM) "withinbetween interaction" ANOVA] with $>80 \%$ power. However, variability in responses to naloxone may exist, so we targeted a sample of 20 subjects per group for a total of 80 subjects. This sample size was calculated to provide $>90 \%$ power to detect a significant difference between groups on visual analog scale (VAS) pain ratings.

\section{Randomization procedure}

Randomization was stratified so that each sex would have their respective list of randomization codes. Males and females were randomized without replacement across a block of 80 codes using an Excel-based random number generator. The four treatment arms (1, 2,3 , and 4) were permuted with respect to treatment assignment (meditation + naloxone, control + naloxone, meditation + saline, control + saline) in a double-blind fashion. Participants were informed of their respective group assignment after completion of Experimental Session 1.

\section{Stimuli}

As described previously (Quevedo and Coghill, 2007; Starr et al., 2009; Yelle et al., 2009; Zeidan et al., 2011; Lobanov et al., 2014), MEDOC TSA-II (Medoc) was used to deliver all thermal stimuli using a $16 \mathrm{~mm}^{2}$ surface area thermal probe. To reduce habituation, the thermal probe was moved to a new stimulation site after each experimental series. All stimulus temperatures were $\leq 49^{\circ} \mathrm{C}$ and subjects were free to escape the stimulator at any time by lifting their limb from a custom-made probe holder.

\section{Psychophysical assessment of pain}

As described previously (Zeidan et al., 2011; Zeidan et al., 2015), pain intensity and unpleasantness ratings were assessed with a $15 \mathrm{~cm}$ plastic sliding VAS (Price et al., 1994). We instructed subjects that "the distinction between the two aspects of pain might be made clearer if you think of listening to a sound, such as a radio. The intensity of pain is like loudness; the unpleasantness of pain depends not only on intensity, but also on other factors which may affect you" (Price et al., 1983). The minimum rating ("0") was designated as "no pain sensation" and "not at all unpleasant," whereas the maximum ("10") was labeled as "most intense pain sensation imaginable" or "most unpleasant sensation imaginable," respectively. These scales have been demonstrated to provide reliably separate assessment of pain intensity and unpleasantness, to be internally consistent, and to approximate ratio scale measurement accuracy (Price, 2000).

\section{Drug administration}

A $0.15 \mathrm{mg} / \mathrm{kg}$ bolus dose of naloxone (Naloxone $\mathrm{HCl}$; Amphastar Pharmaceuticals) or saline in $25 \mathrm{ml}$ of normal saline was administered over 10 min via the intravenous line inserted into the antecubital vein of the nondominant arm. Onset of naloxone-induced opioidergic antagonism (after intravenous administration) occurs within 2 min and exhibits an average half-life of 64 min ("Summary of Product," Amphastar Pharmaceuticals). Importantly, the duration of the experiment from the onset of naloxone infusion to completion was $22 \mathrm{~min}$. However, to further ensure that naloxone would antagonize opioid receptors for entirety of the experiment, we administered a supplementary intravenous infusion dose of $0.1 \mathrm{mg} / \mathrm{kg} / \mathrm{h}$ naloxone or saline immediately after bolus infusion ceased until the end of the experiment $(\sim 12 \mathrm{~min})$. This large dose comprehensively antagonizes endogenous opioids (Levine and Gordon, 1986) and is larger than dosages previously used to successfully reverse analgesia produced by placebo (Levine et al., 1978; Grevert et al., 1983; Amanzio and Benedetti, 1999; Benedetti et al., 1999), electrical stimulation of periventricular gray matter (Adams, 1976; Hosobuchi et al., 1977), transcranial magnetic stimulation (de Andrade et al., 2011; Taylor et al., 2013), and acupuncture (Mayer et al., 1977). We employed a slightly lower naloxone infusion dosage than other high-dose naloxonepain focused studies (Eippert et al., 2009; Sprenger et al., 2012; Schoell et al., 2010) to reduce the exhibition of naloxone-related side effects that 
Table 1. Group demographics, weight, baseline pain ratings, and naloxone symptom assessments

\begin{tabular}{|c|c|c|c|c|c|c|}
\hline & Meditation + naloxone & Control + naloxone & Meditation + saline & Control + saline & $F$ & $p$-value \\
\hline Age & $27.25(2.07)$ & $26.55(1.39)$ & $26.6(1.24)$ & $27.25(1.46)$ & 0.06 & 0.98 \\
\hline Weight (kg) & $69.10(2.08)$ & $78.03(4.15)$ & $74.78(3.85)$ & $76.43(3.54)$ & 1.26 & 0.30 \\
\hline Drug/saline dosage (mg) & $12.08(0.36)$ & $13.65(0.72)$ & $13.09(0.68)$ & $13.37(0.61)$ & 1.28 & 0.29 \\
\hline Baseline VAS pain intensity & $5.34(0.40)$ & $4.74(0.49)$ & $4.18(0.39)$ & $5.60(0.51)$ & 2.00 & 0.12 \\
\hline Baseline VAS pain unpleasantness & $5.36(0.41)$ & $4.96(0.54)$ & $4.59(0.45)$ & $5.68(0.52)$ & 0.98 & 0.40 \\
\hline \multicolumn{7}{|l|}{ Naloxone symptom assessment } \\
\hline Dry mouth & $1.5(0.33)$ & $0.94(0.32)$ & $0.95(0.27)$ & $0.74(0.31)$ & 1.14 & 0.34 \\
\hline Dry skin & $0.40(0.18)$ & $0.61(0.26)$ & $0.30(0.21)$ & $0.58(0.26)$ & 0.43 & 0.74 \\
\hline Blurred vision & $0.05(0.15)$ & $0.11(0.08)$ & $0.15(0.15)$ & $0.16(0.12)$ & 0.22 & 0.88 \\
\hline Sedation & $0.35(0.15)$ & $0.50(0.20)$ & $0.40(0.22)$ & $0.42(0.26)$ & 0.09 & 0.97 \\
\hline Nausea & 0 & $0.06(0.06)$ & $0.06(0.06)$ & $0.16(0.12)$ & 0.97 & 0.41 \\
\hline Dizziness & $0.05(0.05)$ & $0.17(0.09)$ & $0.05(0.05)$ & $0.16(0.16)$ & 0.46 & 0.71 \\
\hline Headache & $0.15(0.08)$ & $0.06(0.06)$ & $0.15(0.08)$ & 0 & 1.29 & 0.29 \\
\hline Drowsy & $2.11(0.57)$ & $2.91(0.59)$ & $2.26(0.47)$ & $1.65(0.51)$ & 0.89 & 0.45 \\
\hline Excited & $1.42(0.40)$ & $2.12(0.30)$ & $1.11(0.32)$ & $1.62(0.42)$ & 1.31 & 0.26 \\
\hline Feeble & $2.59(0.64)$ & $2.27(0.44)$ & $1.46(0.44)$ & $1.25(0.30)$ & 1.83 & 0.15 \\
\hline Clear-headed & $1.14(0.44)$ & $2.35(0.59)$ & $1.14(0.26)$ & $1.36(0.47)$ & 0.04 & 0.99 \\
\hline Clumsy & $1.13(0.43)$ & $2.35(0.59)$ & $1.14(0.26)$ & $1.36(0.47)$ & 1.64 & 0.19 \\
\hline Energetic & $6.05(0.46)$ & $6.16(0.55)$ & $6.82(0.50)$ & $6.57(0.60)$ & 0.47 & 0.70 \\
\hline Discontented & $1.03(0.32)$ & $1.97(0.51)$ & $1.01(0.38)$ & $1.68(0.49)$ & 1.25 & 0.30 \\
\hline Tranquil & $8.36(0.51)$ & $8.09(0.54)$ & $8.64(0.25)$ & $7.55(0.54)$ & 0.98 & 0.41 \\
\hline Quick-witted & $7.48(0.43)$ & $7.34(0.45)$ & $7.67(0.32)$ & $7.30(0.65)$ & 0.13 & 0.94 \\
\hline Relaxed & $8.60(0.28)$ & $7.24(0.49)$ & $8.65(0.25)$ & $7.51(0.52)$ & 3.34 & 0.02 \\
\hline Dreamy & $3.86(0.69)$ & $3.07(0.47)$ & $2.64(0.49)$ & $1.86(0.42)$ & 2.44 & 0.07 \\
\hline Proficient & $8.08(0.38)$ & $8.06(0.37)$ & $8.45(0.27)$ & $8.29(0.37)$ & 0.28 & 0.84 \\
\hline Sad & $0.82(0.32)$ & $1.86(0.37)$ & $1.14(0.58)$ & $1.02(0.26)$ & 1.17 & 0.33 \\
\hline Amicable & $9.02(0.27)$ & $8.24(0.35)$ & $9.02(0.22)$ & $9.42(1.07)$ & 0.68 & 0.57 \\
\hline Bored & $2.37(0.57)$ & $3.54(0.58)$ & $1.45(0.35)$ & $2.43(0.46)$ & 2.94 & 0.04 \\
\hline Gregarious & $6.49(0.59)$ & $7.06(0.35)$ & $7.71(0.29)$ & $6.83(0.48)$ & 1.37 & 0.26 \\
\hline Insecure & $1.23(0.40)$ & $1.58(0.34)$ & $0.63(0.19)$ & $1.02(0.26)$ & 1.76 & 0.16 \\
\hline
\end{tabular}

may lead to drug assignment un-blinding. Only the study physicians, research pharmacist, and research coordinator were aware of participant-drug assignment. Subjects, research nurses, and all experimenters were blinded to drug assignment.

\section{Experimental design}

\section{Experimental Session 1 (psychophysical training and baseline} pain testing)

Subjects were initially familiarized with 32 5-s-duration stimuli (35$49^{\circ} \mathrm{C}$ ) and use of the VAS (Zeidan et al., 2011; Emerson et al., 2014; Lobanov et al., 2014). Stimuli were delivered to the ventral aspect of the left forearm. Baseline (preintervention) psychophysical responses to noxious heat were then assessed by administering two heat series. Heat series ( 4 min and $24 \mathrm{~s}$ ) included 10 alternating, $12 \mathrm{~s}$ plateaus of $49^{\circ} \mathrm{C}$ and $35^{\circ} \mathrm{C}$ stimulation to the back of the right calf. The thermal probe was moved to a different region on the back of the right calf after completion of the first heat series. VAS pain intensity and unpleasantness ratings were collected after each series. After successful completion of sensory testing, participants were instructed of their respective group assignment (i.e., meditation or control).

\section{Experimental Sessions 2-5: group training sessions}

Mindfulness meditation training regimen. As in previous studies (Zeidan et al., 2011; Zeidan et al., 2015), subjects in the meditation group participated in 4 separate days $(20 \mathrm{~m} / \mathrm{d})$ of mindfulness-based mental training. Subjects were informed that meditation training was secular and taught as the cognitive practice of mindfulness meditation. Across all of the meditation training sessions, subjects were instructed to focus on the changing sensations of the breath while using a nonevaluative cognitive state. Time providing guided meditative instructions was progressively reduced across meditation training days to allow subjects to meditate in silence (Zeidan et al., 2010a, 2010b, 2010c; 2011, 2014).

In each meditation training session, mindfulness-based instructions emphasized acknowledging arising thoughts, feelings, and/or emotions without judgment or emotional reaction and to "simply return their attention back to the breath" sensation whenever such discursive events occurred. Subjects were also taught that perceived sensory/ affective events were "momentary" and "fleeting" and did not require further interpretation or evaluation. In meditation training session 1 , subjects were instructed to focus on the breath sensations occurring "at the tip of the nose." In meditation training session 2 , subjects were instructed to expand their focus to the "full flow of the breath," including bodily sensations (e.g., rise and fall of the abdomen and chest). On meditation training days 3 and 4 , subjects received minimal meditation instructions. Contrary to traditional mindfulness-based training programs, subjects were not instructed to practice outside of training.

Book listening control regimen. The control group listened to an audio recording of The Natural History of Selborne (White, 1908) across $4 \mathrm{~d}(20$ $\mathrm{m} / \mathrm{d}$ ). This group was used to control for facilitator attention and the time elapsed in the other interventions. Subjects were not allowed to sleep, use their phones, or talk to the experimenter during book listening.

\section{Experimental Session 6}

After successful completion of respective group interventions, subjects reported to Wake Forest School of Medicine's Clinical Research Unit (CRU). CRU nurses first administered an opiate-focused urine drug screening to confirm that no subjects were using opioids and to minimize the chance that opioid-dependent individuals would experience withdrawal during naloxone administration. Weight was subsequently measured to confirm the prescribed drug dosage. A CRU nurse then inserted the IV catheter into the nondominant arm of each subject. For safety purposes, blood pressure, respiration rate, oxygen saturation, and heart rate data were systematically monitored and recorded throughout the entire experiment. Finally, subjects placed their right calf on a custommade thermal probe holder and were provided with an overview of the experimental procedures before the testing phase of the experiment.

Rest. Two heat series were administered. VAS pain intensity and unpleasantness ratings were collected after each series. The thermal probe 
was moved to a different location of the right calf after each heat series to reduce potential habituation and sensitization.

Naloxone/saline administration. After the first two heat series, a research nurse initiated the naloxone/placebo infusion. Participants in the meditation group were instructed to "begin meditating until the end of the experiment." Control group subjects were told to "close your eyes and relax until the end of the experiment."

Manipulation (meditation/control). Two more heat series were administered during meditation or rest (i.e., control condition). VAS pain intensity and unpleasantness ratings were collected after each series and the thermal probe was moved to a different location of the right calf after each heat series. After completion of the experiment, blood pressure readings were collected and participants were assessed for potential naloxone-related symptoms.

\section{Analysis of behavioral data}

Behavioral data were analyzed with SPSS 19.0 software (IBM).

\section{Pain ratings}

Psychophysical assessment of pain from baseline (Experimental Session 1) and Experimental Session 6 were analyzed separately. In Experimental Session 1, group differences in pain intensity and unpleasantness ratings were examined with a single-factor ANOVA to assess for potential baseline (preintervention) group differences.

In Experimental Session 6, a two-factor ANOVA tested the hypothesis that meditating in the presence of saline and noxious heat stimulation would produce significantly lower pain intensity and unpleasantness ratings compared with rest, meditating in the presence of naloxone, and control. Significant $(p<0.05)$ main effects and interactions were investigated with planned post hoc tests (Bonferroni-adjusted $\alpha$ level of .013 per test) comparing the percentage change (from rest to manipulation) in pain intensity and unpleasantness ratings (Toothaker, 1993; Cohen and Lea, 2004).

\section{Secondary outcomes}

Univariate ANOVA analyses examining potential group differences on demographics (age, weight), drug dosage, and outcomes corresponding to the naloxone symptoms checklist (Bentley et al., 2004; Eippert et al., 2009) were conducted.

\section{Results}

\section{Baseline pain ratings across groups}

Before intervention training, there were no significant baseline (i.e., Session 1) differences among groups for pain intensity $\left(F_{(3,74)}=2.00, p=0.12\right)$ or unpleasantness $\left(F_{(3,74)}=0.99, p=0.40\right)$ ratings (Table 1 ).

\section{Naloxone and mindfulness-meditation-induced analgesia Pain intensity} The RM ANOVA conducted on pain intensity ratings exhibited a significant main effect of rest/manipulation $\left(F_{(1,74)}=4.22, p=\right.$

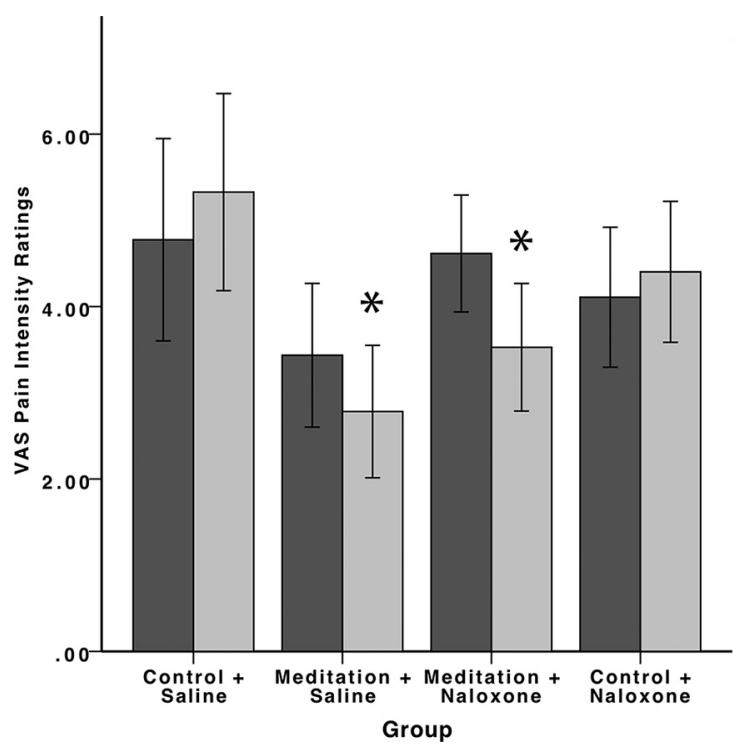

Figure 1. Psychophysical pain intensity ratings ( $\pm 95 \%$ confidence intervals). Meditation during saline (meditation + saline) infusion significantly $(p<0.001)$ reduced pain intensity and unpleasantness ratings compared with rest and the control and saline (control + saline) group. Importantly, naloxone failed to reverse meditation-induced analgesia. Meditation during naloxone administration (meditation + naloxone) significantly $(p<0.001)$ reduced pain intensity ratings compared with rest, the control + saline group, and the control and naloxone (control + naloxone) groups. There were no significant differences in pain intensity reductions $(p=0.69)$ between the meditation + saline and the meditation + naloxone groups.

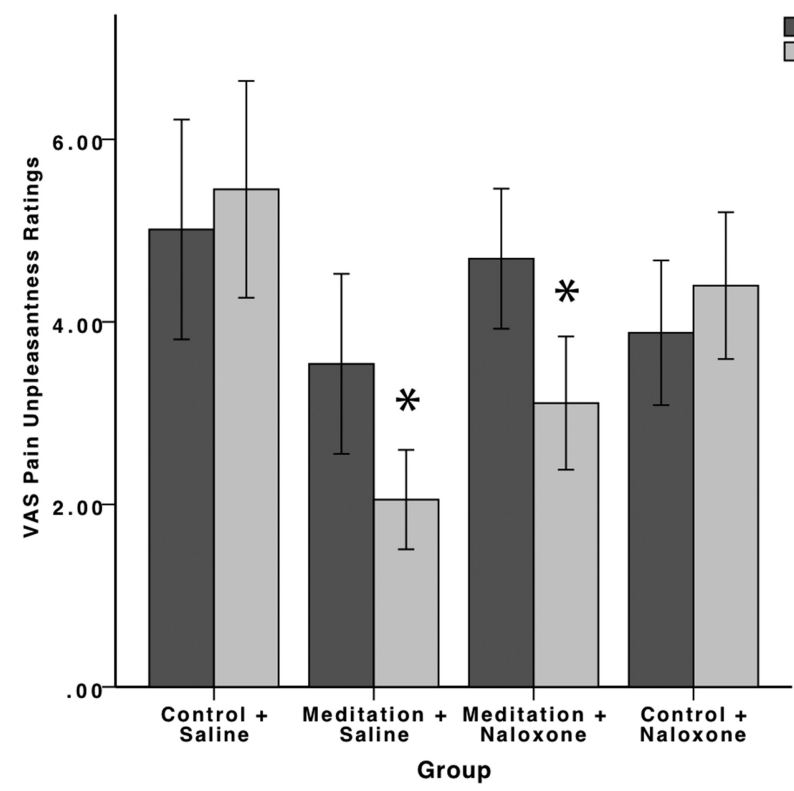

Figure 2. Psychophysical pain unpleasantness ratings ( $\pm 95 \%$ confidence intervals). Meditation during saline (meditation + saline) infusion significantly $(p<0.001)$ reduced pain unpleasantness compared with rest and the control and saline (control + saline) group. Naloxone did not reverse meditation-induced pain relief. Meditation during naloxone administration (meditation + naloxone) significantly $(p<0.001)$ reduced pain unpleasantness ratings compared with rest, the control + saline group and the control and naloxone (control + naloxone) groups. There were also no significant differences in pain intensity reductions ( $p=$ $0.75)$ between the meditation + saline and the meditation + naloxone groups.

$\left.0.043, \eta_{p}^{2}=0.05\right)$. There was also a significant main effect of $\operatorname{group}\left(F_{(3,74)}=3.85, p=0.01, \eta_{\mathrm{p}}^{2}=0.14\right)$. However, a univariate ANOVA found no significant between-group differences on pain intensity ratings at rest $\left(F_{(3,74)}=2.03, p=0.12\right)$. Importantly, there was a significant rest/manipulation $\times$ group interaction $\left(F_{(3,74)}=12.86, p<0.001, \eta_{\mathrm{p}}^{2}=0.34\right)$ (Fig. 1).

A priori independent-samples $t$ tests were conducted on the percentage change in pain intensity ratings to investigate the sig- 
Table 2. Characteristics associated with naloxone infusion-related side effects

\begin{tabular}{|c|c|c|c|c|c|c|c|c|}
\hline $\begin{array}{l}\text { Subject } \\
\text { ID }\end{array}$ & Group & Sex & Weight & Symptoms & $\begin{array}{l}\text { BP during } \\
\text { baseline }\end{array}$ & $\begin{array}{l}\text { BP during naloxone- } \\
\text { induced side effects }\end{array}$ & $\begin{array}{l}\text { HR during } \\
\text { baseline }\end{array}$ & $\begin{array}{l}\text { HR during naloxone- } \\
\text { induced side effects }\end{array}$ \\
\hline A & Meditation + naloxone & Female & $60.2 \mathrm{~kg}$ & Syncope, vomiting & $104 / 64$ & $70 / 40$ & 94 bpm & $74 \mathrm{bpm}$ \\
\hline B & Control + naloxone & Female & $57.4 \mathrm{~kg}$ & $\begin{array}{l}\text { Cloudy vision, excessive } \\
\text { perspiration, chest pressure }\end{array}$ & $112 / 66$ & $69 / 41$ & $65 \mathrm{bpm}$ & $55 \mathrm{bpm}$ \\
\hline$C$ & Control + naloxone & Female & $69.5 \mathrm{~kg}$ & Lightheadedness & $111 / 68$ & $96 / 55$ & $55 \mathrm{bpm}$ & $85 \mathrm{bpm}$ \\
\hline D & Control + naloxone & Female & $46.7 \mathrm{~kg}$ & Lightheadedness & $116 / 71$ & $85 / 59$ & 74 bpm & 61 bpm \\
\hline
\end{tabular}

$\mathrm{BP}$, Blood pressure; $\mathrm{HR}$, heart rate; bpm, beats per minute.

nificant interaction and to test study's hypotheses. Mindfulness meditation in the presence of saline significantly reduced $(p<$ $0.001)$ pain intensity ratings $(-21 \%)$ compared with the control group during saline administration $(+21 \%)$. Importantly, naloxone failed to reverse meditation-induced reductions in pain intensity ratings. That is, there were no significant differences in the percentage change in pain intensity reductions produced by meditation in the presence of naloxone $(-24 \%)$ compared with meditation in the presence of saline $(p=0.69)$. Furthermore, meditation in the presence of naloxone significantly reduced $(p<0.001)$ pain intensity ratings compared with the control + saline and the control + naloxone $(+11 \%)$ groups.

\section{Pain unpleasantness}

The RM ANOVA on pain unpleasantness ratings detected a significant main effect of rest/manipulation $\left(F_{(3,74)}=14.93, p<\right.$ $\left.0.001, \eta_{\mathrm{p}}^{2}=0.17\right)$ and a main effect of group $\left(F_{(3,74)}=6.04\right.$, $\left.p=0.001, \eta_{\mathrm{p}}^{2}=0.20\right)$. However, univariate ANOVA confirmed no significant between-groups differences in pain unpleasantness ratings at rest $\left(F_{(3,74)}=2.26, p=0.09\right)$. There was also a rest/ manipulation $\times$ group interaction $\left(F_{(3,74)}=18.09, p<0.001\right.$, $\eta_{\mathrm{p}}^{2}=0.42$ ) (Fig. 2).

Follow-up independent-samples $t$ tests comparing the percentage change in pain unpleasantness ratings between groups found that meditation during saline administration significantly reduced $(p<0.001)$ pain unpleasantness ratings $(-36 \%)$ compared with the control group during saline administration $(+18 \%)$. Similar to the analysis on pain intensity ratings, naloxone did not reverse meditation-induced reductions in pain unpleasantness ratings. There were no significant differences between the meditation groups in the presence of naloxone and saline $(p=0.75)$. Meditation during naloxone administration $(-33 \%)$ also significantly reduced pain unpleasantness compared with the control + saline $(p<0.001)$ and control + naloxone $(p<0.001 ;+15 \%)$ groups.

\section{Naloxone-related side effects}

Four participants (data not included in the results) were withdrawn from the study due to side effects associated with naloxone infusion (Table 2). We discontinued infusion immediately after subjects reported any discomfort and all four subjects were discharged from the study after medical evaluation. Subject "A" experienced syncope $\sim 8$ min after initiation of the naloxone bolus. The subject lost consciousness and was "unresponsive and pale." Upon regaining consciousness (after $\sim 3 \mathrm{~min}$ ), the participant had an episode of vomiting. After being taken to the emergency department, the subject's blood pressure and heart rate elevated to normal levels and she was also no longer symptomatic. The subject later revealed that she had history of syncope. Subject "B" reported feeling "hot with chest pressure" 7 minutes after initiation of the naloxone bolus. Almost immediately after the infusion was discontinued, the subject reported feeling "fine" and her blood pressure and heart rate returned to baseline levels (22 min after the infusion was halted). Subject "C" reported feel- ing "lightheaded" nine minutes after naloxone bolus induction. During this time, her blood pressure decreased and heart rate increased (Table 2). However, her heart rate and blood pressure returned to baseline levels $\sim 10 \mathrm{~min}$ after discontinuation of naloxone infusion. The subject later revealed a history of "feeling lightheaded when anxious." Subject "D" reported feeling "lightheaded" $\sim 13$ min after naloxone infusion began. At the onset of this episode, the subject's blood pressure and heart rate decreased (Table 2). However, the subject reported "feeling better" and her blood pressure and heart rate returned to baseline levels $\sim 10 \mathrm{~min}$ after discontinuing naloxone.

After the completion of Session 6, subjects rated seven items used in previous studies (Bentley et al., 2004; Petrovic et al., 2008; Eippert et al., 2009) to assess potential adverse effects of naloxone. Each adverse effect was rated with a numerical rating scale $(0-6)$ as "inexistent" (0), "very weak" (1), "weak" (2), "moderate" (3), "strong" (4), "very strong" (5), or "extremely strong" (6). In the subjects with no overt adverse effects, naloxone did not produce potentially unblinding subjective effects and there were no significant differences between groups in self-reported ratings of dry mouth, dry skin, blurred vision, sedation, nausea, dizziness, and headache (all $p>0.33$; Table 1 ). To further confirm this, all participants were asked whether they "were able to identify if they received naloxone or saline" after Experimental Session 6 and 76. Seventy-six of the 78 participants answered "no." One subject correctly identified assignment to the naloxone condition and the other participant incorrectly identified assignment to the naloxone condition (i.e., subject received saline).

\section{Discussion}

In the present study, a high dose of the opioid antagonist naloxone failed to reverse mindfulness-meditation-induced analgesia. Mindfulness meditation significantly reduced both pain intensity and unpleasantness ratings during saline administration. During naloxone administration, the pain intensity and unpleasantness reductions associated with mindfulness meditation remained almost completely unaltered. This finding is particularly striking in that the nonmeditation control groups exhibited a significant increase in pain intensity and unpleasantness ratings during the infusion period compared with rest (Figs. 1, 2).

In addition to opioidergic mechanisms, there is a myriad of neurotransmitter systems that are associated with endogenous analgesia (Millan, 2002). Therefore, the present findings cannot address the involvement of any other single neurotransmitter mechanism in mindfulness-meditation-related pain relief. Instead, in light of the present study's findings and our previous neuroimaging work, we propose that mindfulness meditation is a complex, cognitive process that likely engages multiple brain networks and neurochemical mechanisms to attenuate pain.

Converging lines of evidence suggest that pain relief produced by mindfulness meditation is mediated by multiple neural mechanisms (Zeidan et al., 2012; Grant, 2014). First, mindfulness- 
meditation-induced pain relief is associated with greater activation in the lateral $\mathrm{OFC} /$ ventral-lateral $\mathrm{PFC}$, and rostral ACC, brain regions associated with altering the contextual evaluation of pain (Zeidan et al., 2011; Zeidan et al., 2015). Importantly, mindfulness-meditation-induced pain relief is also associated with reduced thalamic activity, which may be related to significantly attenuated low-level sensory processing (Zeidan et al., 2011).

We have repeatedly shown that greater mindfulness-meditation-induced pain relief is associated with greater activation of the OFC (Zeidan et al., 2011; Zeidan et al., 2015). Interestingly, projections from the OFC synapse on the thalamic reticular nuclei (TRN), thin-layered structures that, in turn, inhibit sensory processing in the thalamus (Jones, 1975; Crick, 1984; McAlonan et al., 2000; Zikopoulos and Barbas, 2012). All feedback connections between the cortex and thalamus must pass through the TRN in a topographically organized fashion (Pinault, 2004; Zikopoulos and Barbas, 2006, 2012). Therefore, the TRN may operate as an attentional "gatekeeper" of sensory information (Crick, 1984) by suppressing ascending "irrelevant/distracting" sensory events from reaching the level of conscious awareness (Guillery et al., 1998; Weese et al., 1999; McAlonan et al., 2000; Sherman, 2001; McAlonan et al., 2006; Barbas and Zikopoulos, 2007; Rauschecker et al., 2010; Zikopoulos and Barbas, 2012). We propose that mindfulness-meditation-induced activation of the OFC activates the TRN, which subsequently inhibits thalamic processing to ultimately diminish the distribution of nociceptive information throughout the cortex (Zeidan et al., 2011; Zeidan et al., 2012; Rauschecker et al., 2015). That is, mindfulness meditation may activate the proposed gating mechanism through executive shifts in attention and nonjudgmental reappraisal of noxious sensations.

The present study demonstrates that the meta-cognitive ability to acknowledge and let go of arising sensory events engages a unique, self-facilitated pain modulatory system. Although we have shown repeatedly that mindfulness meditation significantly reduces pain after a brief mental training regimen (Zeidan et al., 2010a; Zeidan et al., 2011; Zeidan et al., 2015), these findings show that meditation reduces pain independently of opioidergic neurotransmitter mechanisms. Because opioid and non-opioid mechanisms of analgesia interact in a synergistic manner, the present work suggest that the combination of mindfulness-based and pharmacologic/nonpharmacologic analgesic strategies that rely on opioid signaling may be particularly effective in the treatment of pain.

\section{References}

Adams JE (1976) Naloxone reversal of analgesia produced by brain stimulation in the human. Pain 2:161-166. CrossRef Medline

Adler LJ, Gyulai FE, Diehl DJ, Mintun MA, Winter PM, Firestone LL (1997) Regional brain activity changes associated with fentanyl analgesia elucidated by positron emission tomography. Anesth Analg 84:120-126. Medline

Amanzio M, Benedetti F (1999) Neuropharmacological dissection of placebo analgesia: expectation-activated opioid systems versus conditioning-activated specific subsystems. J Neurosci 19:484-494. Medline

Bandura A, O'Leary A, Taylor CB, Gauthier J, Gossard D (1987) Perceived self-efficacy and pain control: opioid and nonopioid mechanisms. J Pers Soc Psychol 53:563-571. CrossRef Medline

Barbas H, Zikopoulos B (2007) The prefrontal cortex and flexible behavior. Neuroscientist 13:532-545. CrossRef Medline

Basbaum AI, Fields HL (1984) Endogenous pain control systems: brainstem spinal pathways and endorphin circuitry. Annu Rev Neurosci 7:309-338. CrossRef Medline

Beitz AJ (1982) The organization of afferent projections to the midbrain periaqueductal gray of the rat. Neuroscience 7:133-159. CrossRef Medline
Benedetti F, Arduino C, Amanzio M (1999) Somatotopic activation of opioid systems by target-directed expectations of analgesia. J Neurosci 19: 3639-3648. Medline

Bentley P, Husain M, Dolan RJ (2004) Effects of cholinergic enhancement on visual stimulation, spatial attention, and spatial working memory. Neuron 41:969-982. CrossRef Medline

Bingel U, Lorenz J, Schoell E, Weiller C, Büchel C (2006) Mechanisms of placebo analgesia: $\mathrm{rACC}$ recruitment of a subcortical antinociceptive network. Pain 120:8-15. CrossRef Medline

Casey KL, Svensson P, Morrow TJ, Raz J, Jone C, Minoshima S (2000) Selective opiate modulation of nociceptive processing in the human brain. J Neurophysiol 84:525-533. Medline

Cohen BH, Lea RB (2004) Essentials of statistics for the social and behavioral sciences. Hoboken, NJ: Wiley.

Crick F (1984) Function of the thalamic reticular complex: the searchlight hypothesis. Proc Natl Acad Sci U S A 81:4586-4590. CrossRef Medline

de Andrade DC, Mhalla A, Adam F, Texeira MJ, Bouhassira D (2011) Neuropharmacological basis of rTMS-induced analgesia: the role of endogenous opioids. Pain 152:320-326. CrossRef Medline

Eippert F, Bingel U, Schoell ED, Yacubian J, Klinger R, Lorenz J, Büchel C (2009) Activation of the opioidergic descending pain control system underlies placebo analgesia. Neuron 63:533-543. CrossRef Medline

Emerson NM, Zeidan F, Lobanov OV, Hadsel MS, Martucci KT, Quevedo AS, Starr CJ, Nahman-Averbuch H, Weissman-Fogel I, Granovsky Y, Yarnitsky D, Coghill RC (2014) Pain sensitivity is inversely related to regional grey matter density in the brain. Pain 155:566-573. CrossRef Medline

Floyd NS, Price JL, Ferry AT, Keay KA, Bandler R (2000) Orbitomedial prefrontal cortical projections to distinct longitudinal columns of the periaqueductal gray in the rat. J Comp Neurol 422:556-578. CrossRef Medline

Grant JA (2014) Meditative analgesia: the current state of the field. Ann N Y Acad Sci 1307:55-63. CrossRef Medline

Grevert P, Albert LH, Goldstein A (1983) Partial antagonism of placebo analgesia by naloxone. Pain 16:129-143. CrossRef Medline

Guillery RW, Feig SL, Lozsádi DA (1998) Paying attention to the thalamic reticular nucleus. Trends Neurosci 21:28-32. CrossRef Medline

Hosobuchi Y, Adams JE, Linchitz R (1977) Pain relief by electrical stimulation of the central gray matter in humans and its reversal by naloxone. Science 197:183-186. CrossRef Medline

Jones AK, Qi LY, Fujirawa T, Luthra SK, Ashburner J, Bloomfield P, Cunningham VJ, Itoh M, Fukuda H, Jones T (1991) In vivo distribution of opioid receptors in man in relation to the cortical projections of the medial and lateral pain systems measured with positron emission tomography. Neurosci Lett 126:25-28. CrossRef Medline

Jones EG (1975) Some aspects of the organization of the thalamic reticular complex. J Comp Neurol 162:285-308. Medline

King CD, Goodin B, Kindler LL, Caudle RM, Edwards RR, Gravenstein N, Riley JL 3rd, Fillingim RB (2013) Reduction of conditioned pain modulation in humans by naltrexone: an exploratory study of the effects of pain catastrophizing. J Behav Med 36:315-327. CrossRef Medline

Levine JD, Gordon NC (1986) Method of administration determines the effect of naloxone on pain. Brain Res 365:377-378. CrossRef Medline

Levine JD, Gordon NC, Fields HL (1978) The mechanism of placebo analgesia. Lancet 2:654-657. Medline

Liebeskind JC, Guilbaud G, Besson JM, Oliveras JL (1973) Analgesia from electrical stimulation of the periaqueductal gray matter in the cat: behavioral observations and inhibitory effects on spinal cord interneurons. Brain Res 50:441-446. CrossRef Medline

Lobanov OV, Zeidan F, McHaffie JG, Kraft RA, Coghill RC (2014) From cue to meaning: brain mechanisms supporting the construction of expectations of pain. Pain 155:129-136. CrossRef Medline

Mantyh PW (1983a) Connections of midbrain periaqueductal gray in the monkey. I. Ascending efferent projections. J Neurophysiol 49:567-581. Medline

Mantyh PW (1983b) Connections of midbrain periaqueductal gray in the monkey. II. Descending efferent projections. J Neurophysiol 49:582-594. Medline

Mayer DJ, Price DD, Rafii A (1977) Antagonism of acupuncture analgesia in man by the narcotic antagonist naloxone. Brain Res 121:368-372. CrossRef Medline

McAlonan K, Brown VJ, Bowman EM (2000) Thalamic reticular nucleus 
activation reflects attentional gating during classical conditioning. J Neurosci 20:8897-8901. Medline

McAlonan K, Cavanaugh J, Wurtz RH (2006) Attentional modulation of thalamic reticular neurons. J Neurosci 26:4444-4450. CrossRef Medline

Millan MJ (2002) Descending control of pain. Prog Neurobiol 66:355-474. CrossRef Medline

Petrovic P, Kalso E, Petersson KM, Ingvar M (2002) Placebo and opioid analgesia- imaging a shared neuronal network. Science 295:1737-1740. CrossRef Medline

Petrovic P, Pleger B, Seymour B, Klöppel S, De Martino B, Critchley H, Dolan RJ (2008) Blocking central opiate function modulates hedonic impact and anterior cingulate response to rewards and losses. J Neurosci 28: 10509-10516. CrossRef Medline

Pinault D (2004) The thalamic reticular nucleus: structure, function and concept. Brain Res Brain Res Rev 46:1-31. CrossRef Medline

Price DD (2000) Psychological and neural mechanisms of the affective dimension of pain. Science 288:1769-1772. CrossRef Medline

Price DD, McGrath PA, Rafii A, Buckingham B (1983) The validation of visual analogue scales as ratio scale measures for chronic and experimental pain. Pain 17:45-56. CrossRef Medline

Price DD, Bush FM, Long S, Harkins SW (1994) A comparison of pain measurement characteristics of mechanical visual analogue and simple numerical rating scales. Pain 56:217-226. CrossRef Medline

Quevedo AS, Coghill RC (2007) Attentional modulation of spatial integration of pain: evidence for dynamic spatial tuning. J Neurosci 27:1163511640. CrossRef Medline

Rauschecker JP, Leaver AM, Mühlau M (2010) Tuning out the noise: limbic-auditory interactions in tinnitus. Neuron 66:819-826. CrossRef Medline

Rauschecker JP, May ES, Maudoux A, Ploner M (2015) Frontostriatal gating of tinnitus and chronic pain. Trends Cogn Sci 19:567-578. CrossRef Medline

Schoell ED, Bingel U, Eippert F, Yacubian J, Christiansen K, Andresen H, May A, Buechel C (2010) The effect of opioid receptor blockade on the neural processing of thermal stimuli. PLoS One 5:e12344. Medline

Sherman SM (2001) Tonic and burst firing: dual modes of thalamocortical relay. Trends Neurosci 24:122-126. CrossRef Medline

Sprenger C, Eippert F, Finsterbusch J, Bingel U, Rose M, Büchel C (2012) Attention modulates spinal cord responses to pain. Curr Biol 22:10191022. CrossRef Medline

Starr CJ, Sawaki L, Wittenberg GF, Burdette JH, Oshiro Y, Quevedo AS, Coghill RC (2009) Roles of the insular cortex in the modulation of pain: insights from brain lesions. J Neurosci 29:2684-2694. CrossRef Medline

Taylor JJ, Borckardt JJ, Canterberry M, Li X, Hanlon CA, Brown TR, George MS (2013) Naloxone-reversible modulation of pain circuitry by left prefrontal rTMS. Neuropsychopharmacology 38:1189-1197. CrossRef Medline

Toothaker LE (1993) Multiple comparison procedures. Newbury Park, CA: Sage.

Tracey I, Ploghaus A, Gati JS, Clare S, Smith S, Menon RS, Matthews PM (2002) Imaging attentional modulation of pain in the periaqueductal gray in humans. J Neurosci 22:2748-2752. Medline

Wager TD, Scott DJ, Zubieta JK (2007) Placebo effects on human mu- opioid activity during pain. Proc Natl Acad Sci U S A 104:11056-11061. CrossRef Medline

Watkins LR, Mayer DJ (1982) Organization of endogenous opiate and nonopiate pain control systems. Science 216:1185-1192. CrossRef Medline

Weese GD, Phillips JM, Brown VJ (1999) Attentional orienting is impaired by unilateral lesions of the thalamic reticular nucleus in the rat. J Neurosci 19:10135-10139. Medline

White G (1908) Natural history and antiquities of Selborne. London: Cassell.

Willoch F, Tölle TR, Wester HJ, Munz F, Petzold A, Schwaiger M, Conrad B, Bartenstein P (1999) Central pain after pontine infarction is associated with changes in opioid receptor binding: a PET study with 11Cdiprenorphine. AJNR Am J Neuroradiol 20:686-690. Medline

Willoch F, Schindler F, Wester HJ, Empl M, Straube A, Schwaiger M, Conrad B, Tölle TR (2004) Central poststroke pain and reduced opioid receptor binding within pain processing circuitries: a [11C]diprenorphine PET study. Pain 108:213-220. CrossRef Medline

Yelle MD, Oshiro Y, Kraft RA, Coghill RC (2009) Temporal filtering of nociceptive information by dynamic activation of endogenous pain modulatory systems. J Neurosci 29:10264-10271. CrossRef Medline

Zeidan F, Gordon NS, Merchant J, Goolkasian P (2010a) The effects of brief mindfulness meditation training on experimentally induced pain. J Pain 11:199-209. CrossRef Medline

Zeidan F, Johnson SK, Gordon NS, Goolkasian P (2010b) Effects of brief and sham mindfulness meditation on mood and cardiovascular variables. Journal of alternative and complementary medicine 16:867-873. CrossRef Medline

Zeidan F, Johnson SK, Diamond BJ, David Z, Goolkasian P (2010c) Mindfulness meditation improves cognition: evidence of brief mental training. Conscious Cogn 19:597-605. CrossRef Medline

Zeidan F, Martucci KT, Kraft RA, Gordon NS, McHaffie JG, Coghill RC (2011) Brain mechanisms supporting the modulation of pain by mindfulness meditation. J Neurosci 31:5540-5548. CrossRef Medline

Zeidan F, Grant JA, Brown CA, McHaffie JG, Coghill RC (2012) Mindfulness meditation-related pain relief: evidence for unique brain mechanisms in the regulation of pain. Neurosci Lett 520:165-173. CrossRef Medline

Zeidan F, Martucci KT, Kraft RA, McHaffie JG, Coghill RC (2014) Neural correlates of mindfulness meditation-related anxiety relief. Soc Cogn Affect Neurosci 9:751-759. Medline

Zeidan F, Emerson NM, Farris SR, Ray JN, Jung Y, McHaffie JG, Coghill RC (2015) Mindfulness-meditation-based pain relief employs different neural mechanisms than placebo and sham mindfulness meditation-induced analgesia. J Neurosci 35:15307-15325. CrossRef Medline

Zikopoulos B, Barbas H (2006) Prefrontal projections to the thalamic reticular nucleus form a unique circuit for attentional mechanisms. J Neurosci 26:7348-7361. CrossRef Medline

Zikopoulos B, Barbas H (2012) Pathways for emotions and attention converge on the thalamic reticular nucleus in primates. J Neurosci 32:5338 5350. CrossRef Medline

Zubieta JK, Bueller JA, Jackson LR, Scott DJ, Xu Y, Koeppe RA, Nichols TE, Stohler CS (2005) Placebo effects mediated by endogenous opioid activity on mu-opioid receptors. J Neurosci 25:7754-7762. CrossRef Medline 